\title{
Impact of Some Socioeconomic Factors of Parents on The Quality of Life of Leukemic Children
}

\author{
Abdelmoniem A. Dawah*, Soad DarwishElgendy ${ }^{*}$, Mahmoud Ali Saleh*, Omyma \\ Mahmoud Hassan* And Mayada Said Saadoun*** \\ *Department of Community Medicine, Faculty of Medicine, Benha University, Benha, Egypt \\ *** Medical officer of Epidemiology at the National Surveillance Unit in Egypt
}

\begin{abstract}
Introduction: Acute lymphocytic leukemia (ALL) is the most common malignancy in Egyptian children and has been among the 5 top prevalent pediatric cancers in Egypt, its proportion from total cancer cases is $6.4 \%$. Objective: is to determine the effect of socioeconomic factors of the parents on the quality of life of leukemic children. Methods: Cross sectional study had been carried out at the national cancer institute in Cairo governorate, from July 2012 till January 2013 on 7-14 years old children. 388 recently diagnosed ALL children had been identified through reviewing the medical records from outpatient clinics of the national cancer institute in Cairo governorate; Demographic data had been collected from the parents of the child to get reliable information, as this kind of questions was too hard to a child to answer accurately, while data of the second section had been collected directly from the child. The first case was selected randomly then the third one was selected in randomly systematic way. Results: More than $80 \%$ of the study population belongs to low and very low social classes. The study shows there is statistically significant relation between the socioeconomic class and physical activity, child relation with his peers, and school progress quality of life domains. The most important predictor in SES was the income Conclusion: Most of the very low socioeconomic class children reported lower physical activity, social function, and school progress quality of life rather than low and middle socioeconomic class.
\end{abstract}

Keywords: Leukemia, children, socioeconomic status, Egypt

\section{Introduction}

Acute Lymphocytic Leukemia (ALL) is the most common malignancy in children of Egypt and has been among the 5 to prevalent pediatric cancers in Egypt. The percent of pediatric cancer is high $(6.4 \%)$, when compared to the pediatric cancer incidence in the USA $1 \%$. ALL constitutes $33.2 \%$ of pediatric malignancies and $70 \%$ of pediatric leukemia, The male to female ratio is 2.3:1, and the maximum affected age group is from 2-10years old ${ }^{(\mathbf{1})}$

The chance of an individual developing ALL depends on both genetic and nongenetic factors or environmental factors which are much more important than genetic factors. ${ }^{(2)}$

The cure rate for pediatric ALL has improved from $15 \%$ in the late 1960 s to approximately $80 \%{ }^{(3)}$. A good prognosis is associated with female gender, age at diagnosis between 2 and 10 years, a low white blood cell count, and an early positive response to treatment. ${ }^{(4)}$

Most studies on health-related quality of life (HRQOL) in children with cancer focused on survivors. Only a few studies had been conducted with pediatric cancer patients during the acute phase of the disease. These
Vol. 33

No. 2

April

2015 
studies suggested that HRQOL in children during therapy was significantly lower than in survivors that have completed treatment or in normal population ${ }^{(5)}$ Several studies have noted a decline in the quality of life in leukemic children ${ }^{(6)}$. Recently, there have been studies of quality of life (QOL) in pediatric patients with cancer, but most have focused on survivors and terminally ill

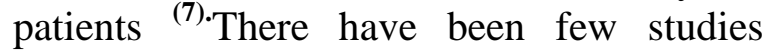
conducted during the treatment phase of the illness. In these recent studies, we have seen that the QOL is less in patients with active treatment than in those survivors who have completed treatment ${ }^{(5)}$.

Over the last years, the interest in assessing social inequalities and health has increased. Socioeconomic characteristic have been associated with morbidity and mortality discrepancies in many developed countries (8). Relationship between social inequalities and cancer has been well studied for adults (9) but less extensively for childhood cancer and childhood leukemia ${ }^{(3)}$.

Cancer registry survival analyses have shown that adolescent and young adult patients with low socioeconomic status (SES) have reduced survival compared to those with higher SES ${ }^{(10)}$.

\section{Objective Of The Study}

To determine the impact of socioeconomic factors of the parents on the quality of life of leukemic children.

\section{Subjects And Methods}

It is a cross sectional study, carried out at the National Cancer Institute in Cairo governorate, from July 2012 till January 2013.

The recently diagnosed ALL children had been identified through reviewing the medical records to exclude any case doesn't match with the selection criteria.
Full explanation of the study had been done to the child and his parents.

The acceptance of the parent collected through signing study consent.

The outpatient clinics visited daily to select the participant who met the inclusion criteria.

\section{Sample size}

Assuming that prevalence of low quality of life among ALL children is $50 \%$, taking in consideration that the study power $80 \%$, elphe error 0.05 , a confidence limit $95 \%$, the minimal required sample was 388 .

Computer program EPI- Info version 6.04 was used for calculation of the minimum sample size required. The following sample size equation was applied.

$n^{t}=\frac{\mathbf{N Z 2} \mathbf{P}(\mathbf{1}-\mathbf{P})}{f(\mathbf{N}-)+\mathbf{Z 2} \mathbf{P}(\mathbf{1}-\mathbf{P})}$

$\mathrm{N}^{\prime}=$ Sample size

$\mathrm{N}=$ Population size,

$\mathrm{Z}=\mathrm{Z}$ statistic for a level of confidence,

$\mathrm{P}=$ Expected proportion (in proportion of one)

$\mathrm{D}=$ Design effect

The sample was selected using systematic random sampling technique (first case selected randomly, and then the second one was selected).

\section{Inclusion criteria:}

- Children with the diagnosis of ALL between 1 month and 2 years prior to the present study

- The leukemic child under maintenance therapy

- No other chronic disease expect ALL

- $\quad$ Age range of 7-14 years

- Children with standard ALL (i.e. a white blood cells count less than 50000/fL, absence of chromosomal anomalies and documented response to therapy in the first month of treatment) 


\section{Exclusion criteria:}

- Lack of interest of parents to cooperate in the study.

- The study protocol was approved by the Ethics Committee of Faculty of medicine, Benha University

- A previously validated reliable questionnaire used to assess the quality of life of the children ${ }^{11}$. The first part of the questionnaire included demographic data, modified to contain details about the socioeconomic status, including parents' education, job, residence, number of the family, type of healthcare service, and income. Demographic data had been collected from the parents of the child to get reliable information, as this kind of questions was too hard to a child to answer accurately, while data of the second section had been collected directly from the child.

The second part contained 4 sections describing the quality of life in the previous 30 days.

The first section describes the physical activity of the ALL child,

Which is composed of eight detailed questions describes the physical condition of the child.

The second section describes the psychological status of the child, which is composed of five questions trying to get the actual image of the psychological status regarding anxiety, fears of future, sleeping disturbance, etc. of the ALL child under treatment.

The third section describes the relation between the child and his peers, which composed of five questions describing the child relation to his friends and peers. Regarding capability of playing with them, avoidance, mocking, etc.
The last one describes the school progress of the child, which composed of five questions highlighting the child concentration status, his capability to do his homework, memory status, etc. ${ }^{11}$

The quality of life of the ALL children had been scored as following:

\begin{tabular}{|l|l|}
\hline 4 & Never had the problem \\
\hline 3 & Rarely had the problem \\
\hline 2 & Sometimes had the problem \\
\hline 1 & Most of the time had the problem \\
\hline 0 & Always had the problem \\
\hline
\end{tabular}

Measurement of the socioeconomic status scored as following: according to Fahmy and El-Sherbiny ${ }^{(10)}$ SES of ALL children was classified as:

\begin{tabular}{|l|l|}
\hline $19-25$ & High socioeconomic class \\
\hline $12-18$ & Middle socioeconomic class \\
\hline $6-11$ & Low socioeconomic class \\
\hline$<6$ & Very low socioeconomic class \\
\hline
\end{tabular}

\section{Total score $=25$}

\section{Statistical method:}

Data was analyzed using SPSS version 16. Quantitative data is summarized by calculating the mean and standard deviation, while the qualitative data is summarized by frequency and percentage. Chi Square test had been used to measure the association between qualitative variables. Quantitative data were examined for normality using graphical method (histogram). Differences between quantitative variables were tested using the Student's t-test and ANOVA test. Multiple linear regressions had been used to measure the predictor factor of SES that affects QOL score of children.

\section{Pilot test:}

The questionnaire was tested on a convenient sample of 26 children (13 male and 13 female) who the target population of the study. Those participated in the pilot 
study were excluded from the main study. Testing of the questionnaire was useful in estimating the time taken to answer the questions and understanding of the questions. This helped to reduce limitations of understanding as well as non - response to questions.

\section{Results}

Table 1 illustrates that $60.8 \%$ the studied group were males, $60.1 \%$ of the sampled children came from rural areas of different governorates. None of them were from private schooling system, $87.1 \%$ went to governmental schools. Two thirds were in primary stage. Also $70.4 \%$ of the sampled cancer children have 3 or more siblings. Finally, it shows that $86.1 \%$ of the study population belongs to the low and very low social classes. Table 2 shows that there was statically significant difference between male and female children as regards psychological status and child physical activity QOL domains of ALL children Table 3 illustrates that there was no statically significant difference between child residences and all QOL domains of ALL children. It was illustrated from table 4 that mean and standard deviation of physical activity and relation of the child with peers QOL domains were statistically significant increase in primary school stage.

Table 5 clearly shows statistically significant association between the social class and the physical activity QOL score. As the highest percentage of very low physical activity which is $49.4 \%$ are from the very low socioeconomic class. On the other hand the highest percentage of high physical activity $48.2 \%$ among those of the middle socioeconomic class $(\mathrm{p} \leq 0.001)$. Similarly, there is significant association between the social class and way the child deal with his peers. As the highest percentage $93.5 \%$ of very low quality of life of how the child is dealing with his peers is from the very low socioeconomic class. Also, there is statistically significant association between the social class and way the child progress in school. As $81.2 \%$ of the sampled children who achieving very low school progress are from the very low socioeconomic class. On the contrary, there is no statistically significant association between the socioeconomic class and the psychological status of the study group. Table 6 the table shows that there is highly significant relationship between school progress quality of life scores and the father education. The highest average score of the school progress $(36.7 \pm 19.9 \mathrm{SD})$ noticed to be among university fathers. On the contrary table 7 shows that there is no statistically significant association between the mother education and the quality of life scores of the study group. Table $\mathbf{8}$ clearly shows that there is statistically significant relationship between physical activity, school progress quality of life scores and father occupation of the studied group. The highest average scores of physical activity quality of life $56.19 \pm 24.4$ SD intermediate group. While the highest average scores of school progress $42.4 \pm 14.4$ SDreported to be among the intermediate group as well. Also, table 9 shows that there is highly statistically significant relationship between child psychological status, social function and school progress quality of life scores, and mother occupation. The highest average scores of psychological status and school progress $(41.8 \pm 12.1 \mathrm{SD}),(47.5 \pm 20.5 \mathrm{SD})$ reported to be in the unskilled mothers and skilled working mothers respectively. Table 10 clearly shows that there was statistically significant difference between father educations, mother occupation and QOL score (p0.024-0.01) and the most predictor factor was the income B (1.96) 


\section{Discussion}

The study results showed that there is highly significant association between the social class and the physical activity score. As the highest percentage of very low physical activity which are reported from the very low socioeconomic class. So socioeconomic class tends to affect the physical activity of the child, this agrees with Bansal et $\boldsymbol{a l}^{(12)}$ and Sung et al. ${ }^{(13)}$ who found that quality of life domains are remarkably low in the lower socioeconomic classes. This could be explained by the relation between the income of the family and providing the child with the required supportive treatment as families stated that they do not get all the prescribed treatments for free from the cancer institute. Also inability to buy the required healthy food during treatment period.

Regarding the social class and the psychological status of the children the results showed that there is no difference between psychological status among different socioeconomic classes. Which is opposing to Pool et al. ${ }^{(14)}$ who find significant relation between the psychological function and the social class. This could be explained by the religion affiliation of the community, as most of the children stated that it is their fate and they are accepting God will.

The study results revealed statistically significant association between the social class and way the child deal with his peers. The child dealing with his peers scored very low in almost all of children belonging to the very low and low socioeconomic class respectively. This could be explained by culture of the very low socioeconomic class, lack of education and privacy. Many children reported that their friends gave him up when they knew that he is sick, others mock him because his hair started to fall, and some families asked their children to avoid him because of the disease is communicable or they believe it is bad vow to see their children playing with cancer child. They even stated that they refuse to name it as cancer even they prefer to call it bad disease because they afraid of its fatality. So lack of education and uncertainty about the ALL tends to play crucial role in the quality of life of ALL children (Pool et al., ${ }^{(14)}$.

The study shows that there is statistically highly significant association between the social class and child progress in school. This result agrees with Sung et al. ${ }^{(\mathbf{1 3})}$ general results about socioeconomic status and quality of life who found the same result. This could be explained by that, the lower the socioeconomic status the less interest in education. They do not appreciate the value of schooling. They are too poor to think about education of the children. So they send their children to the school but they do not care about his grades and even if they care, they cannot afford to help them in the educational process because either they are not educated or they do not have money to afford them private lessons to help them to compensate the dropped lessons. So it is vicious cycle even if the child is willing and committed to schooling all the economic and health issues opposing him.

Our study revealed that there is statistically significant relationship between school progress quality of life scores and the father education. The highest average scores of school progress were reported with the fathers who reached the university, in comparison to illiterate fathers. These results came in agreement with that of Pool et al. ${ }^{(14)}$ who explained that by the higher education fathers get the higher the follow up, monitoring, and motivation of the child to continue his educational progress. May be also explained by what mentioned before in

Vol. 33 No. 2 April 2015


the relation between the socioeconomic class and school progress. The higher the education the higher income the father get, which support in a way or another educational process as stated by the families. In contrast we found that mother education can not affect the quality of life of children this is in agreement with Meeske et al ${ }^{(15)}$ who found that health-related quality of life in pediatric patients diagnosed with brain tumors and acute lymphoblastic leukemia not affected by mother education.

Another cross sectional study was done by sitaresmi et al $2008^{(6)}$ to assess the HRQOL in childhood acute lymphoblastic leukemia (ALL) patients in Indonesia and to assess the influence of demographic and medical characteristics on HRQOL. They found that there was no significant difference between parental educational status and socioeconomic status.

Also our study highlighted that there is statistically significant relationship between physical activity, and school progress quality of life scores and father occupation. The highest average scores of physical activity quality of life were reported among the intermediate working group. While the highest average scores of school progress were reported to be among the intermediate group as well. This could be explained by the impact of income on the socioeconomic class as reported in our study before. As the school progress in the intermediate group comes consistent with the school progress in fathers, who achieve college degree, and physical activity reported as low and very low in the low and the very low socioeconomic class and these results also are consistent with those of Pool et al.. ${ }^{(14)}$

It has been clearly found that there is highly statistically significant relationship between child psychological status and school progress quality of life scores, and mother occupation. The highest average scores of psychological status and school progress were reported to be in the unskilled mothers and the skilled ones. This could be explained again by the direct relation between the socioeconomic standard and supporting the ALL child. As the mother ability to support her child psychologically and to maintain his school progress improve with her social standard. The most important predictor for ALL leukemia in this study was the income.

Of her studies ${ }^{(16-17)}$ fond that high levels of parental education, measured individually, have been consistently associated with a lower risk of childhood leukemia while the association of paternal occupational class with childhood leukemia demonstrates a contrary association, i.e. high rates are correlated with high SES, including findings from 2 cohort studies. ${ }^{(18-19)}$

A recent case-control study conducted in United Kingdom did not show any difference in childhood ALL risk according to deprivation levels, whether using area- or individual-based measure of SES (father's occupation), at the time of birth or diagnosis. ${ }^{(20)}$ On the basis of their findings, the authors suggest that SES in the United Kingdom does not have influence on the quality of life of ALL in children.

Conclusion: Most of the study group classified as very low socioeconomic class, while the rest classified as low and middle. Most of the very low socioeconomic class ALL children reported lower physical activity, social function, and school progress quality of life rather than in low and middle socioeconomic class. There was no relation between the psychological status of the ALL children and the socioeconomic class. Further analysis of the data showed statistically significant relation between the father education and occupation and mother 
occupation with some of the quality of life domains of ALL children.

Recommendations: The following interventions should be implemented to improve the quality of life of the leukemic children: Special schooling system for cancer children, which allow the child to continue his school, without missing his classes and exams to improve the educational progress of the cancer children, psychological therapy for cancer children especially at the time of diagnosis and before starting treatment, aiming to alleviate the child fears, explaining the disease, course of treatment and motivating him During the treatment, health education programs should be implemented to raise the awareness about the chemotherapy treatment side-effects, explaining how to overcome and when to report immediately in order to avoid any fatality and to improve the quality of life, psychological group support for the child and his family. Lastly, Health education campaigns about cancers causes and prevention should be a addressed to public specially those at higher risk.

\section{References}

1) National Cancer Institute (NCI). (2012): Childhood Cancer Survivor Study: An Overview. Cited on, 2012, May 10, from, http://www.cancer.gov/cancertopics/copi ng/ccss

2) Cancerconnect (2013): Childhood Acute Lymphoblastic Leukemia:

Screening/Prevention cited on 2013, April10,from, http://news.cancerconnect.com/childhoo d-acute-lymphoblastic-leukemiascreeningprevention/

3) Pui CH and Jeha S (2007): New therapeutic strategies for the treatment of acute lymphoblastic leukaemia. Nat. Rev. Drug Discov.; 6:149-65.

4) Margolin JF, Steuber CP and Poplack DG (2002): Acute lymphoblastic leukemia. In P.A. Pizzo \& Poplack DG (Eds). Principles and practice of pediatric oncology. 4th ed.489-544.

5) Landolt MA, Vollrath M, Niggli FK, Gnehm HE and Sennhauser FH (2006): Health related quality of life in children with newly diagnosed cancer: a one year follow-up study. Health Qual Life Outcomes; 4:63. [16987419] [http://dx.doi.org/10.11 86/1477-75 254-63]

6) Sitaresmi MN, Mostert S, Gundy Ch, Sutary $M$ and Veerman AJP (2008). Health related quality of life assessment in Indonesian childhood acutelymphoplastic leukemia, Health and Quality of Life Outcomes, This article is available from: http://www.hqlo.com/content/6/1/96

7) Shankar S (2005): Health-related quality of life in young survivors of childhood cancer using the MinneapolisManchester Quality of Life-Youth Form. Pediatrics, 115:435-442.

8) Singh Gk (2003): Area deprivation and widening inequalities in US mortality, 1969-1998. Am J Public Health; 93: 1137-43.

9) Kogevians M, Pearce N, Susser $M$ and Boffetta P, eds (1997): Social inequalities and cancer. Lyon: international agency for research on cancer.

10) Fahmy, S.I. and El-Sherbini,A.F. (1983): Determining simple parameters for social classification for health 
research. Bulletin of the High Institute of Public Health;235:1-14

11) Varni JW, Burwinkle TM, Katz ER, Meeske K, Dickinson P (2002):

The PedsQL in pediatric cancer: reliability and validity of the Pediatric Quality of Life Inventory Generic Core Scales, Multidimensional Fatigue Scale, and Cancer Module. Cancer. 94(7):2090-2106

12) Bansal M, Kamlesh $K$, Sharma Vasta $M$ and Bakhshi S (2013):Comparison of health-related quality of life of children during maintenance therapy with acute lymphoblastic leukemia versus siblings and healthy children in India. Pub Med 54(5):1036-41. doi: 10.3109/10428194.2012.736985.

13) Sung L, Yanofsky R, Klaassen RJ, Dix D, Pritchard S, Winick N, Alexander $S$ and Klassen A (2011): Quality of life during active treatment for pediatric acute lymphoblastic leukemia. PubMed 1;128(5):1213-20.doi:10.1002/ jc.25433.

14) Pool C, Green Land $S$, Luetters $C$, Kelsey JL and Mezei G (2005): socioeconomic status and childhood leukemia: a review. Int J. Epidemiol; 35: 370-840.

15) Meeske K, Katz ER, Palmer SN, Burwinkle TV and Arni JW (2004): Parent proxy-reported health-related quality of life and fatigue in pediatric patients diagnosed with brain tumors and acute lymphoblastic leukemia. Cancer; $101: 21,16-25$.

16) Wong DI and Dockerty JD (2006): Birth characteristics and the risk of childhood leukemias and lymphomas in New Zealand: a case-control study. BMC Blood Disord; 6 : 5-11.

17) Fulton JP, Cobb S, Preble L, Leone L and Forman E (1980): Electrical wiring configurations and childhood leukemia in Rhode Island. Am J Epidemiol; 111:292-6.

18) Dickinson HO and Parker L (1999): Quantifying the effect of population mixing on childhood leukemia risk: the Seascale cluster. Br J Cancer; 81:14451.

19) Murray L, McCarron $P$, Bailie $K$, Middleton R, Davey Smith G, Dempsey S, McCarthy A, Gavin A (2002): Association of early life factors and acute lymphoblastic leukemia in childhood: historical cohort study. Br J Cancer; 86:356-61.

20) Smith A, Roman E, Simpson J, Ansell P, Fear NT and Eden T. (2006): Childhood leukaemia and socioeconomic status: fact or artifact? A report from the United Kingdom childhood cancer study (UKCCS). Int J Epidemiol; 35:1504-13. 
Table (1): Some socio-demographic characteristics of the study group

\begin{tabular}{|c|c|c|c|}
\hline \multicolumn{2}{|l|}{ Variable } & \multirow{2}{*}{$\begin{array}{l}\text { No }=\mathbf{3 8 8} \\
236\end{array}$} & \multirow{2}{*}{$\begin{array}{l}\text { Percentage \% } \\
60.8 \\
\end{array}$} \\
\hline Child a & Male & & \\
\hline Cimu genuer & Female & 152 & 39.2 \\
\hline \multirow{2}{*}{ Residence } & Urban & 155 & 39.9 \\
\hline & Rural & 233 & 60.1 \\
\hline \multirow{3}{*}{ School type } & Governmental & 338 & 87.1 \\
\hline & Private & 0 & 0.0 \\
\hline & None & 50 & 12.9 \\
\hline \multirow{2}{*}{$\begin{array}{l}\text { Current school stage * } \\
\text { (338 currently in school) }\end{array}$} & Primary & 223 & 66.0 \\
\hline & Preparatory & 115 & 34.0 \\
\hline \multirow{2}{*}{ Number of sibling in the family } & $\leq 3$ & 273 & 70.4 \\
\hline & $>3$ & 115 & 29.6 \\
\hline \multirow{3}{*}{ Social class } & Very low & 154 & 39.7 \\
\hline & Low & 180 & 46.4 \\
\hline & Intermediate & 54 & 13.9 \\
\hline
\end{tabular}

Table (2) : The quality of life domains of the ALL children according to child gender

\begin{tabular}{|l|l|l|l|l||}
\hline \multicolumn{1}{|c|}{ Child gender } & Male & Female & ST t test & P value \\
QOL domains & Mean \pm SD & Mean \pm SD & & \\
\hline \hline Physical activity & $52.86 \pm 24.52$ & $58.33 \pm 24.32$ & 2.12 & 0.034 \\
\hline Psychological status & $27.05 \pm 12.07$ & $32.9 \pm 11.93$ & 4.62 & 0.001 \\
\hline Relation with peers & $22.23 \pm 15.74$ & $25.21 \pm 15.32$ & 1.82 & 0.07 \\
\hline School progress & $32.67 \pm 20.82$ & $29.15 \pm 20.97$ & 1.6 & 0.111 \\
\hline TQOL & $34.61 \pm 12.67$ & $34.26 \pm 12.34$ & 0.268 & 0.789 \\
\hline
\end{tabular}

* Statistically significant 
Table (3): The quality of life domains of the ALL children according to their residence

\begin{tabular}{|l|l|l|l|l||}
\hline $\begin{array}{l}\text { Residence } \\
\text { QOL domains }\end{array}$ & $\begin{array}{l}\text { Rural } \\
\text { Mean } \pm \text { SD }\end{array}$ & $\begin{array}{l}\text { Urban } \\
\text { Mean } \pm \text { SD }\end{array}$ & ST t test & P value \\
\hline Physical activity & $55.25 \pm 24.79$ & $54.49 \pm 24.26$ & 0.296 & 0.767 \\
\hline Psychological status & $30.02 \pm 12.45$ & $28.19 \pm 12.12$ & 1.43 & 0.154 \\
\hline Relation with peers & $22.9 \pm 16.82$ & $24.08 \pm 13.67$ & 0.724 & 0.469 \\
\hline School progress & $30.96 \pm 20.9$ & $31.86 \pm 21.02$ & 0.411 & 0.681 \\
\hline TQOL & $35.64 \pm 12.3$ & $32.66 \pm 12.7$ & 2.27 & $0.024^{*}$ \\
\hline
\end{tabular}

* Statistically significant

Table (4): The quality of life domains of the ALL children according to current school stage

\begin{tabular}{|l|l|l|l|l|}
\hline \hline Qurrent school stage & $\begin{array}{l}\text { Primary } \\
\text { Qean } \pm \text { domains }\end{array}$ & $\begin{array}{l}\text { Preparatory } \\
\text { Mean } \pm \text { SD }\end{array}$ & St t test & P value \\
\hline \hline Physical activity & $56.55 \pm 24.78$ & $51.01 \pm 22.17$ & 2.01 & 0.045 \\
\hline Psychological status & $28.61 \pm 12.09$ & $30.16 \pm 13.32$ & 1.07 & 0.285 \\
\hline Relation with peers & $24.11 \pm 16.25$ & $20.05 \pm 13.71$ & 2.28 & $0.023^{*}$ \\
\hline School progress & $29.77 \pm 21.21$ & $29.02 \pm 18.99$ & 0.316 & 0.753 \\
\hline TQOL & $34.53 \pm 12.68$ & $33.7 \pm 12.62$ & 0.574 & 0.567 \\
\hline
\end{tabular}


Table (5): The association between QOL of the study group and their socioeconomic class

\begin{tabular}{|c|c|c|c|c|c|c|c|c|c|c|c|}
\hline \multirow{2}{*}{\multicolumn{2}{|c|}{ Social grade }} & \multicolumn{2}{|c|}{ Very low } & \multicolumn{2}{|c|}{ Low } & \multicolumn{2}{|c|}{ Middle } & \multicolumn{2}{|c|}{ Total } & \multirow{2}{*}{$X^{2}$ test } & \multirow{2}{*}{$P$ value } \\
\hline & & No. & $\%$ & No. & $\%$ & No & $\%$ & No. & $\%$ & & \\
\hline \multirow{4}{*}{$\begin{array}{l}\text { Physical } \\
\text { activity }\end{array}$} & $\begin{array}{ll}\text { Very } & \text { low } \\
\text { QOL } & \\
\end{array}$ & 76 & 49.4 & 70 & 38.9 & 18 & 33.3 & 164 & 42.3 & \multirow{4}{*}{27.89} & \multirow{4}{*}{$0.001 \mathrm{HS}$} \\
\hline & Low QOL & 42 & 27.3 & 41 & 22.8 & 7 & 13.0 & 90 & 23.2 & & \\
\hline & Middle QOL & 15 & 9.7 & 17 & 9.4 & 3 & 5.6 & 35 & 9.0 & & \\
\hline & High QOL & 21 & 13.6 & 52 & 28.9 & 26 & 48.1 & 99 & 25.5 & & \\
\hline \multirow{2}{*}{$\begin{array}{l}\text { Psychological } \\
\text { status }\end{array}$} & $\begin{array}{ll}\text { Very } & \text { low } \\
\text { QOL } & \\
\end{array}$ & 143 & 92.9 & 167 & 92.8 & 49 & 90.7 & 359 & 92.5 & \multirow{2}{*}{0.29} & \multirow{2}{*}{$0.865 \mathrm{NS}$} \\
\hline & Low QOL & 11 & 7.1 & 13 & 7.2 & 5 & 9.3 & 29 & 7.5 & & \\
\hline \multirow{2}{*}{$\begin{array}{l}\text { Relation with } \\
\text { peers }\end{array}$} & $\begin{array}{ll}\text { Very } & \text { low } \\
\text { QOL } & \\
\end{array}$ & 144 & 93.5 & 161 & 89.4 & 43 & 79.6 & 348 & 89.7 & \multirow{2}{*}{8.35} & \multirow{2}{*}{$0.015 \mathrm{~S}$} \\
\hline & Low QOL & 10 & 6.5 & 19 & 10.6 & 11 & 20.4 & 40 & 10.3 & & \\
\hline \multirow{2}{*}{$\begin{array}{l}\text { School } \\
\text { Progress }\end{array}$} & $\begin{array}{ll}\text { Very } & \text { low } \\
\text { QOL } & \\
\end{array}$ & 120 & 81.2 & 110 & 72.2 & 27 & 59.3 & 257 & 74.0 & \multirow{2}{*}{10.5} & \multirow[t]{2}{*}{0.005 HS } \\
\hline & Low QOL & 25 & 18.8 & 40 & 27.8 & 16 & 40.7 & 81 & 26.0 & & \\
\hline
\end{tabular}

HS = Highly Signification

NS = Not Signification

Table (6): The quality of life of the ALL children according to father education.

\begin{tabular}{|l|l|l|l|l|l|l|l|l||}
\hline \multirow{2}{*}{ EOL } & \multicolumn{2}{|l|}{ Physical activity } & \multicolumn{2}{l|}{$\begin{array}{l}\text { Psychological } \\
\text { status }\end{array}$} & \multicolumn{2}{l|}{ Social function } & \multicolumn{2}{l|}{ School progress } \\
\cline { 2 - 9 } & Mean & \pm SD & Mean & \pm SD & Mean & \pm SD & Mean & \pm SD \\
\hline Illiterate & 55.4 & 24.6 & 30.8 & 12.6 & 24 & 14.9 & 28.8 & 19.7 \\
\hline Read \&write & 43 & 25.1 & 25.1 & 10.8 & 16.7 & 17.5 & 24.4 & 18.9 \\
\hline Primary & 58.9 & 24.0 & 31.3 & 14.5 & 20.7 & 12.1 & 30.3 & 23.1 \\
\hline Preparatory & 52.4 & 26.4 & 24.5 & 6.7 & 22 & 21.4 & 22.1 & 19.9 \\
\hline Secondary & 56 & 22.9 & 28.3 & 13.1 & 24.6 & 16.1 & 26.4 & 21.5 \\
\hline University & 51 & 29.4 & 28.6 & 10.2 & 20.3 & 10.1 & 36.7 & 19.9 \\
\hline F test & 1.31 & & 1.98 & & 1.37 & & 5.29 & \\
\hline P value & $0.259 \mathrm{NS}$ & $0.081 \mathrm{NS}$ & 0.234 & $\mathrm{NS}$ & 0.001 & $\mathrm{HS}$ \\
\hline
\end{tabular}


Table (7): The quality of life of the ALL children according to the mother education

\begin{tabular}{|l|l|l|l|l|l|l|l|l|}
\hline \multirow{2}{*}{$\begin{array}{l}\text { Mother } \\
\text { education }\end{array}$} & \multicolumn{2}{c|}{ Qhysical activity } & \multicolumn{2}{l|}{$\begin{array}{l}\text { Psychological } \\
\text { Status }\end{array}$} & \multicolumn{2}{l|}{ Social function } & \multicolumn{2}{l|}{ School progress } \\
\cline { 2 - 10 } & Mean & \pm SD & Mean & \pm SD & Mean & \pm SD & Mean & \pm SD \\
\hline Illiterate & 54.9 & 25.9 & 29.5 & 12.5 & 22.6 & 15.8 & 31.2 & 21.5 \\
\hline Read \&write & 54.8 & 11 & 34.1 & 14.21 & 29.2 & 7.4 & 35.2 & 18.3 \\
\hline Primary & 81.2 & 18.2 & 37.5 & 10.1 & 12.5 & 9.5 & 62.5 & 20.4 \\
\hline Preparatory & 60.6 & 25.5 & 30.7 & 11.4 & 27.2 & 13.3 & 31.2 & 23.5 \\
\hline Secondary & 51.4 & 23.6 & 26.8 & 12.6 & 23.10 & 17.2 & 28.7 & 19.8 \\
\hline University & 55.5 & 19.1 & 31.5 & 8.8 & 24.1 & 8.5 & 32.9 & 19.2 \\
\hline F test & 1.44 & & 1.72 & & 1.04 & & 1.76 & \\
\hline P value & $0.21 \mathrm{NS}$ & $0.13 \mathrm{NS}$ & $0.392 \mathrm{NS}$ & $0.12 \mathrm{NS}$ & \\
\hline
\end{tabular}

Table (8): The quality of life of the ALL children according to father occupation.

\begin{tabular}{|c|c|c|c|c|c|c|c|c|}
\hline \multirow{2}{*}{$\begin{array}{l}\qquad \text { QOL } \\
\qquad \begin{array}{l}\text { Father } \\
\text { occupation }\end{array}\end{array}$} & \multicolumn{2}{|c|}{ Physical activity } & \multicolumn{2}{|c|}{$\begin{array}{l}\text { Psychological } \\
\text { status }\end{array}$} & \multicolumn{2}{|c|}{ Social function } & \multicolumn{2}{|c|}{ School progress } \\
\hline & Mean & \pm SD & Mean & \pm SD & Mean & \pm SD & Mean & \pm SD \\
\hline $\begin{array}{l}\text { Not working or } \\
\text { retired }\end{array}$ & 52.8 & 18.1 & 32.7 & 11.4 & 22.9 & 10.9 & 27.3 & 20.3 \\
\hline Un skilled & 55.44 & 24.4 & 28.6 & 12.6 & 23.6 & 15.2 & 30.6 & 22.2 \\
\hline Skilled & 43.5 & 25 & 28.2 & 12.6 & 23.4 & 13.6 & 40.5 & 15.6 \\
\hline Intermediate* & 56.19 & 25 & 29.6 & 12.2 & 22.9 & 17.1 & 42.4 & 14.4 \\
\hline F test & \multicolumn{2}{|l|}{2.904} & \multicolumn{2}{|l|}{0.756} & \multicolumn{2}{|l|}{0.058} & \multicolumn{2}{|l|}{6.06} \\
\hline P value & \multicolumn{2}{|l|}{$0.035 \mathrm{~S}$} & \multicolumn{2}{|c|}{$0.519 \mathrm{NS}$} & \multicolumn{2}{|c|}{$0.98 \mathrm{NS}$} & \multicolumn{2}{|c|}{$0.001 \mathrm{HS}$} \\
\hline
\end{tabular}

- Intermediate (low professional, trades, business)

$\mathrm{S}=\mathrm{NS}=\mathrm{HS}=$


Table (9): The quality of life of the ALL children according to mother occupation.

\begin{tabular}{|c|c|c|c|c|c|c|c|c|}
\hline \multirow{2}{*}{$\begin{array}{l}\text { QOL } \\
\text { Mother } \\
\text { occupation }\end{array}$} & \multicolumn{2}{|c|}{$\begin{array}{l}\text { Physical } \\
\text { activity }\end{array}$} & \multicolumn{2}{|c|}{$\begin{array}{l}\text { Psychological } \\
\text { status }\end{array}$} & \multicolumn{2}{|c|}{ Social function } & \multicolumn{2}{|c|}{ School progress } \\
\hline & Mean & $\pm \mathrm{SD}$ & Mean & $\pm \mathrm{SD}$ & Mean & $\pm \mathrm{SD}$ & Mean & \pm SD \\
\hline $\begin{array}{l}\text { Not working } \\
\text { or retired }\end{array}$ & 55.8 & 25.1 & 29.1 & 12.6 & 23.2 & 15.62 & 28.85 & 21.2 \\
\hline Un skilled & 48.4 & 23.0 & 41.8 & 12.1 & 15.6 & 5.31 & 43.13 & 24.2 \\
\hline skilled & 48.1 & 7.5 & 21.2 & 3.4 & 9.4 & 8.56 & 47.5 & 20.5 \\
\hline Intermediate & 48.4 & 22.2 & 27.5 & 10.2 & 26.5 & 16.1 & 40.1 & 15.4 \\
\hline F test & \multicolumn{2}{|l|}{1.66} & \multicolumn{2}{|l|}{4.604} & \multicolumn{2}{|l|}{2.9} & \multicolumn{2}{|l|}{6.67} \\
\hline$P$ value & \multicolumn{2}{|c|}{$0.174 \mathrm{NS}$} & \multicolumn{2}{|c|}{$0.004 \mathrm{HS}$} & \multicolumn{2}{|c|}{$0.034 \mathrm{~S}$} & \multicolumn{2}{|c|}{$0.001 \mathrm{HS}$} \\
\hline
\end{tabular}

$\mathrm{S}=\mathrm{NS}=\mathrm{HS}=$

Table (10) multiple linear regressions of QOL score adjusted for SES status of ALL children.

\begin{tabular}{|l|l|l|l|}
\hline QOL score & B & P value & 95\%CI \\
\hline SES factors & & & \\
\hline Father education & 0.765 & 0.024 & $(-1.43)-)-0.102)$ \\
\hline Mother occupation & 1.63 & 0.01 & $(-2.87)-(-0.396)$ \\
\hline Income & & & \\
\hline
\end{tabular}

